\title{
Study on the origin and evolution of the Chinese batik
}

\author{
DOI: 10.35530/IT.071.03.1694
}

\section{ABSTRACT - REZUMAT}

\section{Study on the origin and evolution of the Chinese batik}

The origin and spread of the Chinese batik have always been a controversial issue in the field of Chinese dyeing and waving historiography. The systemic analysis was carried out by the methods of textile archaeology and literature research in this paper. Conclusions have been made as follows: there were two models in the origin of Chinese batik. One, such as the Central Plains area, was the type of external afference. Another model, such as the south-western ethnic areas, was the type of generating from the inside of the area. The transmutation of batik in Central Plain areas have passed through three stages: introduction from the Eastern Han Dynasty to the Northern and Southern Dynasties, mass acceptance during the Sui Dynasty, Tang Dynasty and Five Dynasties, obsolescence during the Two Song Dynasties. From the perspectives of the reason, the rapid disappearance of batik in the Central Plains areas were caused by the special internal and external environment and the development trend of dyeing technology of the Song Dynasty.

Keywords: batik, origin, transmission, ash resist dye, clamp resist dye

\section{Studiu privind originea și evoluția tehnicii batik în China}

Originea și răspândirea tehnicii batik au reprezentat întotdeauna o problemă controversată în domeniul istoriografiei vopsirii și țeserii din China. Analiza sistemică din această lucrare a fost realizată prin metodele de arheologie textilă și cercetare în literatura de specialitate. Concluziile au fost următoarele: la originea tehnicii batik din China au existat două modele. Unul provine din zona Câmpiei Centrale, reprezentând tipul extern. Un alt model provine din zonele etnice din sud-vest, reprezentând tipul care a fost generat din interiorul zonei. Transmutarea tehnicii batik în zonele Câmpiei Centrale a trecut prin trei etape: introducere din dinastia Han din est în dinastiile din nord și sud, acceptarea în masă în timpul dinastiei Sui, dinastiei Tang și în timpul celor cinci dinastii, ieșirea din uz în timpul celor două dinastii Song. Din perspectivele motivului dispariției acestei tehnici, aceasta a avut loc rapid în zonele Câmpiei Centrale din cauza mediului intern și extern și a tendinței de dezvoltare a tehnologiei de vopsire a dinastiei Song.

Cuvinte-cheie: batik, origine, transmitere, colorant rezistent din cenușă

\section{INTRODUCTION}

As one of the four great fabric dyeing (tie dye, clamp resist dye, wax resist dye and ash resist dye) in China, batik was a highlight in the Central Plains region during the period of the Sui and Tang dynasties. However, batik disappeared in the Central Plain areas after the Song dynasty and there are some historical relics only in south-western ethnic areas today.

Therefore, exploring the problem of the origins and spread of Chinese batik technique plays a very important role in study on essence of extinction of batik in the Central Plains region. The author states that types of origin of Chinese batik technique should be first analysed. Then the division of development stages of it should be carried out. On this basis, the cause of extinction of batik can be summed up in the end.

\section{ORIGIN OF CHINESE BATIK TECHNIQUE}

The origin of Chinese batik has no background of its origin in spinning and dyeing. The author views the origin of Chinese batik technique can be divided into two types: external afference and internal self-generating.

\section{The type of external afference}

The theory of the external afference refers to opinion that Chinese batik technique was obtained from communication with the outside world rather than originated from China. British scholar L.W.C. Miles holds that fabrics with batiks appeared in 1500 B.C. Having studied on the pattern of the Ishtar batik fabric (figure 1) unearthed in Xinjiang, Zhao Feng concluded that it has obvious characteristics of Indian culture. It can be deduced from the conclusion that Chinese batik technique originated from India [1]. Lei Guiuan and Forrest assume that it originated from Java and original timeline is now difficult to identify [2]. 


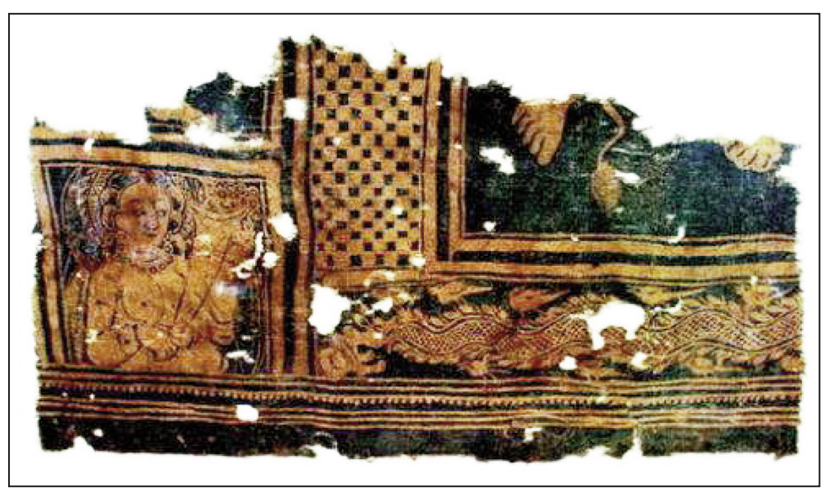

Fig. 1. Ishtar batik fabric

All versions of Song of wax printing, the ancient song of Miao ethnics, show the batik was invented and created by native girls. Second, legend of Miao nationality tells that Chi You, an ancestor of Miao, was defeated and turned into the maple when he died. Miao People apply the maple-leaf juice on their banners and clothes to memorialize Chi You. Thus the secret of resist dyeing had been discovered and has been retained in Basha Miao households in Congjiang, Guizhou province. Therefore, the batik evolved from maple liquid dyeing is Chinese Miao. The batik technique was fully utilized when Miao and Yao (Miao and Yao had genetic relationship and have been deemed as Wuyi Man in Chinese ancient books) had completed their migration to southwest china in Qin and Han Dynasties (220 B.C. - 220 A.D.), which shows that Miao and Yao have had the batik technique before Qin and Han Dynasties. In a word, the time of origin of batik technique in Miao and Yao has far to be earlier than the East Han Dynasty when the batik technique was present in western regions. So, the model of origins of Chinese batik technique is internal self-generation from the angle of minority nationalities.

\section{DEVELOPMENT AND EVOLUTION OF THE BATIK TECHNIQUE IN THE CENTRAL PLAINS OF CHINA}

It is well known that the batik technique of the Central Plain areas stemmed from India and introduced from Western Regions (afferent pathway similar to Buddhism). However, the batik is not the same as Buddhism whose development stretches without a break. It is like a shooting star quickly disappearing in the long river of history. The authors think the development and evolution of the batik in the Central Plain areas undergone three process: Introduction from the Eastern Han Dynasty to the Southern and Northern Dynasties (A.D. 25-589), wide popularity during the period of Sui-Tang and Five Dynasty (A.D. 581-960) and then decline in the Two Song Dynasties (A.D. 960-1279).

Introduction of the batik technique in the Central Plains area

The unearthed textiles, blue wax printing wool fabric and cotton fabric in the Northern Dynasties (A.D. 396-581), of Wuyulaike Site in the Yutian county of Xinjiang are proofs that the batik technique was brought to the center of China from Western Region besides the Ishtar batik fabric. Obviously, these two batik fabrics were not fabricated by artisans of Han nationality. The reasons are as followings:

- Wool fabric is main cloth material of northern minority nationality, silk, ko-hemp and flax are mainly used for the cloth material in the Central Plains Area.

- Cotton fabric introduced as "Tu-gong" from Western Regions and Southwestern ethnic areas and did not spread to Yangtse River Delta Area until the ending of Song and beginning of Yuan Dynast. sons are as follows. 
- The two batik fabrics were discovered in Western Regions, the communications centre of Silk Road. It is well known that Western Regions are the convergent center of West Asia, South Asia and Central Plains civilization. Meanwhile, the related records about the batik fabrics of West Asia and South Asia has emerged greatly early before Anno Domini. Physical batik fabrics did not appear in Central Plains until the period of the Sui and Tang Dynasties.

Therefore, the author holds that the possibility that the batik spread from Western Regions to the Central Plains is high.

Wide popularity of the batik technique in the Central Plains area

During the Sui, Tang and Five Dynasties, the batik quickly became popular in the Central Plains and was rapidly improved in technology, which can be verified with textile archaeology. The Viewpoint that the batik had been popular and developed rapidly in Central Plains was hinted by two evidences: the banners in Mogao Grottoes in Dunhuang and the batik fabrics of the Tang Dynasty had been kept in the Shosoin of Nara in Japan.

Evidence 1: A lot of unearthed batik fabrics of the Tang Dynasty in Mogao Grottoes in Dunhuang. In the 1960s, there were a lot of batik fabrics in banners discovered in Mogao Grottoes, e.g. cloud bird flowergrass patterns on lake blue background of the silk batik, the lucidum flower-bird pattern on deep red background of the silk batik, the cloud and flower-bird pattern on yellow background of the batik silk and the flower pattern on earthy yellow background of the batik silk [5]. The author considers the possibility that they all were made from the Central Plains is great. The reason is as follows: all are silk fabrics. As is known, the Central Plains, silk fabrics' hometown, can provide conditions for silk fabrics manufacturing. Secondly, as early as the Qin and Han Dynasties, the Central Plains people had a tradition of using lucidum, Ruicao and auspicious cloud as "Xiang Rui" patterns in silk fabric. In addition, there was also a kingdom of Gaochang in the Western Regions established by the Han nationality in the Sui and Tang Dynasties. According to researched historical documents, Gaochang was actually a local regime established by Han immigrants who migrated to the Western Regions during the Han-Jin period. The technique of silk weaving of Gaochang was surprisingly excellent, which was verified with the wooden figures of the Kesi belt in Zhangxiong the tomb. Showing the artisans of Han Nationality also had the possibility to apply the batik to silk fabrics. Although the batik fabrics in these flags are not necessarily made by Han artisans in the Central Plains, the possibility is there. Even if the batik fabric painted by Gaochang craftsmen, also conclude that the Han nationality had already begun to apply the batik craft to silk fabrics, this completed the transformation of the wax printing materials from wool and cotton fab- rics to the silk. In the fourteenth year of the Era Zhenguan (640 A.D.), Gaochang was destroyed by LiShimin, Emperor Taizong of the Tang Dynasty (A.D. 599-649). The Tang Dynasty resettled the military and civilian officials of Gaochang, and the dominant power in Gaochang were moved to Chang'an and Luoyang [6]. So the author feels this the result concurred that the batik technique brought to the Central Plains area is because of inner migration of the dignitaries in Gaochang, which promotes its development here.

Evidence 2: The batik fabrics of Tang Dynasty collected in the Shosoin of Nara. Japan. The Shosoin, Warehouse of Japan during Nara time (A.D. 710-794), had housed daily necessities and precious articles of Shengwu Mikado (A.D. 701-756), which include treasures of Chinese antiques, relics of Western Regions and creations made by Japan in imitation of Chinese cultural relics. Therefore, treasures collected in the Shosoin of Nara provided important material for inquiring into the utensils of the Nara time and the flourishing period of Tang Dynasty. Nowadays, a large number of batik products are stored in the Shosoin of Nara even today, among which the batik folding screen with tree and elephant as well as tree and goat design (figure 2) might be the most famous work. It was drawn from dyeing animal hairs with exquisite patterns and elegant tone [7]. Even as the opinions expressed in "Research for the History of Dyeing and Waving" by scholar Akashi Senjin, the famous screen of the Tang Dynasty was imported into Japan as a precious gift of friendship. Although it cannot be concluded that the batik folding screen with tree and elephant as well as tree and goat design came from the Central Plains of Tang Dynasty, there is no doubt that it was welcomed in here, where as the diplomats would have sent it back to Japan.

Wax printing was always a professional behaviour in manual workshop in the Central Plains of Tang Dynasty. In order to maintain the efficiency of printing

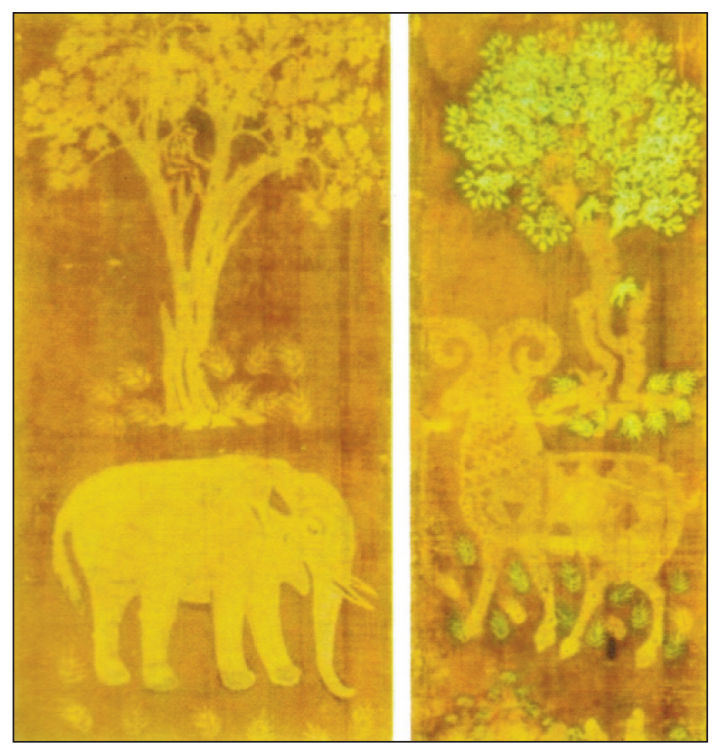

Fig. 2. Batik folding screen with tree and elephant as well as tree and goat 
and guarantee the quality of products, the batik fabrics were mainly produced by the following two methods: i) a small convex template was used to simplify operation; ii) paper type printing was used to further improve production efficiency. The authors think: these two methods are different from manual wax printing or the boards coated with wax of southwest minority area by viewing the mode of production. This suggests that there is little possibility of the batik spread from southwest minority area to the Central Plains. It can also be illustrated that the enormous social demand of the batik fabrics in Tang Dynasty, which standardized production are being obtained to promote its development in the Central Plains of China. People began to popularize application of pattern waxing method after Tang Dynasty. Which laid a foundation for the generation and development of ash resistant dye in the Central Plains area and the batik that replaced by it.

\section{Withered development of the batik in the Central Plains area}

The declining period of the batik in the Central Plains area refers to the period between the two Song Dynasties. At this time, the batik fabric was disappeared almost in Central Plains. Zhou Qufei (A.D. 1135-1189), scholar of Nan Song Dynasty, records Yao people use two pieces of wood with carved patterns to clip the grey cloth, the melted wax goes into the wood patterns, and then dyeing cloth with indigo. The wax is then melted by boiling the cloth to form exquisite pattern [8]. This is particular dyeing method of Yao people the batik was very rare in the Central Plains in the era of Zhou Qufei. Otherwise, he would not have been recorded the, waxing and valerian craft as a kind of odd skill. Exactly what caused the sudden disappearance of batik in Central China is still worth discussing. The author believes it was the sudden extinction of the batik craft in Central Plains that led to the existence of illusion that Chinese batik originated from the southwest minority region.

\section{ANALYSIS ON THE CAUSES OF BATIK EXTINCTION IN THE CENTRAL PLAINS}

Between Northern and Southern Song, the reason for the rapid disappearance of the batik in the Central Plains is generally attributed to the ban on dyeing valerian in the Song Dynasty. It is well known that the extinction of any process is not mainly caused by a certain major factor, but should be considered comprehensively from various factors in the process's internal and external history. The author thinks that the reasons for the rapid disappearance of wax valerian in the Central Plains should be considered from the political environment of Song Dynasty, the economic cost of the batik and the creation of ash resist dye technology.
The Song dynasty dyeing ban was an important political reason for the disappearance of the batik in the folk society

There are strict regulations on the Yufu system in ancient China. The prohibition of dyeing valerian in the civil society is closely related to the Yufu system system.

Such bans were introduced during the Era Xianping of Emperor Zhenzong (998-1003) and Era Tiansheng of Emperor Renzong (1023-1032). The ban imposed during the reign of Emperor Huizong of the Song Dynasty (1082-1135, 1100-1126) was the most severe. According to the records in the historical materials, the dyeing fabric has been widely used in the clothing of the army and guards. In order to strictly separate from the clothing of the common people, the use of dyeing is prohibited to them.

The lack of beeswax in Song Dynasty is an important economic factor to limit the development of the batik

The main raw material for valerian in Central Plains is beeswax. However, beeswax is widely used in Chinese. As early as the Han Dynasty, beeswax was used for the Lighting of royal and noble families [9]. The use of candles can be confirmed in mural painting of Yongtai princess's tomb. There are other important uses for beeswax:

- Used in pharmaceutical production.

- Used in seal of documents. Sealing letters and official documents was an important means to prevent information from leakage in ancient times. It is conceivable that the demand of beeswax is large because of frequent war between the two Song Dynasties.

- Used in cultural trades. Beeswax was an important ingredient in the production of statues and calligraphy mounting. The Song Dynasty, with its thriving culture, must have had a great demand for beeswax.

- Used in all aspects of production and life. In ancient times (including the song dynasty), beeswax was widely used as anti-corrosion and lubricating materials in shoe making, car making, textile and other industries [10]. The beeswax was very widely used in the ancient Central Plains.

Beeswax was very difficult to obtain in the Central Plains of the Song Dynasty, which can be examined from the price of beeswax paid to the court from various places. According to the History of Song Dynasty, Song Hui Yao Ji Gao and Yuan Feng Jiu Yu Zhi, Henan, Shaanxi, Chongqing, Gansu and Anhui all paid less than $50 \mathrm{~kg}$ waxes, and even Pengshui county, Chongqing city, only paid $5 \mathrm{~kg}$ per wax [11]. Beeswax was very expensive, some counties could not even pay $5 \mathrm{~kg}$. Obviously, the beekeeping level in the Tang Dynasty was far lower than that in the Song dynasty. Why did the development of wax resist dye reach its peak in the Tang Dynasty, while gradually disappeared in the Song Dynasty? 
On the one hand, compared with the Song Dynasty, the Tang Dynasty had a vast territory. Even in the early Northern Song Dynasty, its territory was far less than half that of the Tang Dynasty, let alone the Southern Song Dynasty. The areas where beeswax was obtained in the Tang Dynasty were far greater in the Song Dynasty, which could fully compensate for the loss of beekeeping technology lower in the Song Dynasty. According to the New Book of Tang, Gansu, Sichuan, Shaanxi, Hubei, Anhui, Shanxi, Zhejiang, Fujian, Guizhou and other places have paid beeswax as tribute to the imperial court [12]. The Tang Dynasty established 415 Jimi Zhou in the southwest minority regions [13], which includes the major areas of beeswax products. It is not hard to see that the number of beeswax directly obtained in the Central Plains of the Song Dynasty would be much lower than that of the Tang Dynasty.

On the other hand, in the early days of Tang Dynasty, emperor Tai Zong attacked the Turk in the north and the Gaochang in the west, which made the Silk Road run smoothly. At the same time, the Sea Silk Road in the southwest was opened. The strongest period of the Northern Song Dynasty, the north and northwest regions were controlled by the Liao and the Western Xia respectively, and the communication between the land and Central Asia was completely blocked. The southwest regions cannot be effectively controlled and a large-scale war burst in Jiaozhi (Vietnam). At this time in the Northern and Southern Dynasties, only the Sea Silk Road could be used. By comparing the tang and song dynasties, it can be seen that the Tang Dynasty had strong national power, vast territory and smooth traffic between east and west, and the Song Dynasty was the opposite. Therefore, the Song Dynasty had far less means to obtain beeswax from external environments than the Tang Dynasty, which prevented the development of wax resist dye.

The production of ash resist dye in Song Dynasty is an important technical factor for the complete disappearance of the batik

The ash resistant dye is also called Yao ban bu, printing and dyeing by using prepared slurry and resist dyeing technique. Since the song dynasty, it was rising rapidly in Jiangnan regions and is in existence today. According to the Complete Collection of Pictures and Books of Old and New Times, Yao ban bu was originated from Jiading and Anting Towns [14]. From its raw material and technological characteristics, the ash resistant dye is quite suitable for the development in Central Plains. To begin with, the ash resist dye used soybean flours and limes as slurries of resist dye, which is characterized by simple process and low cost. So, it gradually replaced other dyeing and printing technology, and quickly spread from Jiangnan to Jiangbei [15]. In addition, its slurry does not need heating and much simpler than wax resist dye. In the end, due to the stencil frame made for duplicating the blank, it can be produced simultaneously by different printmakers using the same stencil frame, which leads to standardized production. The batik, by contrast, is less likely to achieve this because it needs to heat and use hand drawing. Based on the comparative analysis of the batik and the ash resistant dye in resist dye slurry, and the process characteristics and quality control, the author believes that it is almost a historical necessity for the batik craft to gradually withdraw from people's sight in Central Plains after the production of the ash resistant dye.

\section{CONCLUSIONS}

The results of our research can be summarized as follows:

- The origin of Chinese batik technique can be divided into two types: external afference and Internal self-generating. The origin type of the batik in the Central Plains belongs to the external afferent type, which was introduced from the Indian civilization to the Central Plains through the western regions, and developed a unique dying method in the Central Plains Region. On the contrary, the origin type in the southwest minority region belongs to the type of internal self-generating, which is formed gradually through the migration process of Miao and Yao people and their living environment.

- The development and evolution of the batik in the Central Plain areas have undergone three process: Introduction from the Eastern Han Dynasty to the Southern and Northern Dynasties (A.D. 25-589), wide popularity during the period of Sui-Tang and Five Dynasty (A.D. 581-960) then decline in the Two Song Dynasties (A.D. 960-1279).

- The reasons for the rapid disappearance of wax valerian in the Central Plains should be considered from the internal and external environment and the development trend of dyeing technology. To be specific, the political environment of Song Dynasty, the economic cost of the batik and the creation of ash resist dye technology are the major factor of its demise.

\section{ACKNOWLEDGEMENTS}

The author would like to thank Chinese ministry of education for giving financial support for this study.

\section{REFERENCES}

[1] Zhao, F., Chinese Silk Art History, Chinese Academy of Art Press, Hangzhou, 1992

[2] He, C., Yang, W.B., Province Batik, Soochow University Press, Suzhou, 2009

[3] Xinjiang Uighur Autonomous Region Museum, Culture Unearthed in Xinjiang, Culture Relics Publishing House, Beijing, 1975

[4] Chen, W.J., History of Chinese Textile Science and Technology (Ancient Part), Science Press, Beijing, 1984 
[5] Wang, L., Zhao, F., Study and analysis of existing fabric of Dunhuang banners, In: Dunhuang Research, 2008, 1, $1-9$

[6] Zhang, F.F., Zhang, P., Kingdom Gaochang, China Radio International Press, Beijing, 2013

[7] Bao, Y.Z., Talk on color batik, In: Dyeing \& Finishing, 1985, 3, 25-26

[8] Yu, X.L., Chinese Blue Calico, People's Fine Arts Publishing House, Beijing, 2008

[9] Yang, S.P., Knowledge of the honeybee and technology of bee husbandry in Ancient China, In: Agricultural Archaeology, 1988, 1, 242-251

[10] Ge, F.C., Chen, D.H., Li, Y.F., Time-honoured Changbai bee culture (19) - The Study on beeswax of Chinese Ancient, In: Zhongguo Yangfeng, 1998, 1, 27-28

[11] Zhang, X.Y., The research of bee husbandry in the Song Dynasty, In: Journal of Bee, 2007, 5, 14-16

[12] Guo, R., The research of bee husbandry in the Tang Dynasty, In: The Journal of Chinese Social and Economic History, 2011, 1, 5-10

[13] Fang, T., Discuss in boundary defense thoughts and administrative policy for Chinese southwest borderland in Tang Dynasty, In: Journal of Yunnan Minzu University (Social Sciences), 2001, 2, 51-54

[14] Wu, Y.X., Wu, L.S., The Soul of Gua Jiang Yin Ran - Chinese Blue Calico, Heilongjiang People's Publishing House, Harbin, 2011

[15] Wu, Y.X., Wu, L.S., Blue Allover, China Society Press, Beijing, 2009

\section{Authors:}

LI BIN ${ }^{1}$, ZHAO HONGYAN ${ }^{2}$, LI YIXIAO ${ }^{3}$, JIANG XUEWEI ${ }^{1}$, HONG YU $^{1}$, TAO HUI ${ }^{1}$

${ }^{1}$ Wuhan Textile University, School of Fashion,

Minzu Avenue in Hongshan District, 430073, Wuhan, China

e-mail: libin790121@qq.com, wiiii1i@sina.com

${ }^{2}$ Wuhan Textile University, Hubei Research Center of Intangible Cultural Heritage, Minzu Avenue in Hongshan District, 430073, Wuhan, China

${ }^{3}$ Institute of Textiles\&Clothing, The Hong Kong Polytechnic University, Hong Kong, China

e-mail: 953592363@qq.com

Corresponding authors:

ZHAO HONGYAN

e-mail: 530417418@qq.com

JIANG XUEWEI

e-mail: jxw21981@163.com

TAO HUI

e-mail: 932678733@qq.com 